\title{
SALICYLATES AND THYROID FUNCTION. II. THE EFFECT ON THE THYROID-PITUITARY INTERRELATION
}

\author{
By J. WOLFF AND FRANK K. AUSTEN \\ (From the National Institute of Arthritis and Metabolic Diseases, National Institutes \\ of Health, Bethesda, Md., and Walter Reed Institute of Research and \\ Walter Reed Army Hospital, Washington, D. C.)
}

(Submitted for publication February 4, 1958; accepted April 10, 1958)

In the preceding paper (1) it was pointed out that the administration of sodium salicylate to man induces a number of changes suggestive of thyrotoxicosis. There is an elevated basal metabolic rate (BMR), negative nitrogen balance, a fall in the cholesterol level of the hypothyroid subject, and an accelerated fractional disappearance rate of labeled thyroxine from the circulation. Paradoxically, salicylate-induced hypermetabolism is not accompanied by certain of the clinical characteristics of hyperthyroidism and is associated with depressed thyroid function as measured by thyroidal radioiodine uptake and clearance, or the serum protein bound iodine (PBI) concentration. The salicylate level in the serum of such patients is not high enough to interfere with in vitro iodine metabolism in rat thyroid slices, and in acute experiments in rats no depression of the iodide concentrating mechanism can be demonstrated at blood salicylate levels comparable to those attained in the above patients (1). Similar findings had previously been recorded in rats and in man treated with 2,4-dinitrophenol (2-4). It was subsequently shown (5) that this thyroid depression produced by 2,4-dinitrophenol probably resulted from inhibition at a pituitary or higher level.

The absence of a direct or immediate effect of salicylates on thyroid tissue, despite marked thyroid depression upon more prolonged exposure to the drug, suggested that this effect may also result from a decrease in thyroid stimulation by thyrotropin (TSH). It is the purpose of this report to suggest a locus of salicylate action and to present some observations on the nature of the inhibitory effect.

\section{MATERIALS AND METHODS}

Three euthyroid patients were studied to evaluate the effect of salicylates on the rate of release of radioiodine from the thyroid gland. The technique was similar to that described by Goldsmith, Stanbury, and Brownell
(6). Each patient, while fasting, was given approximately 125 microcuries of radioiodine, and 48 hours later was started on 1-methyl-2-mercaptoimidazole, $30 \mathrm{mg}$. every six hours, to block the reaccumulation of radioiodine. Counts over the thyroid region were measured each morning with a wide angle scintillation counter. Body background was taken as the thigh count, and the logarithm of the counts remaining in the thyroid after correction for body background and physical decay was plotted against time to determine half-life and rate of release of thyroidal $I^{131}$.

Thyrotropin ${ }^{1}$ (TSH), dissolved in physiologic saline and injected intramuscularly, was given during salicylate administration to seven patients in a dose of 5 U.S.P. units every 12 hours. In five patients thyrotropin was started immediately after completion of a 2, 5, and 24 hour uptake of $\mathrm{I}^{181}$. Values were corrected for residual counts remaining from any previous experiment. Two other patients received thyrotropin by the same dose schedule while the thyroidal release rate was being studied.

Release of $\mathrm{I}^{131}$ from the propylthiouracil-blocked rat thyroid was measured according to the method of Wolff (7) with minor modifications. A rate meter operating off the same detector was used to center the thyroid area prior to counting. The diet used was a modified Remington diet; because rats kept on this diet for prolonged periods showed biological half-lives of thyroidal $\mathrm{I}^{131}$ of well under 24 hours, rats were fed this diet for only 12 to 16 days prior to the release studies. Each animal served as its own control and the pooled values of each group were plotted semilogarithmically to obtain half-lives of thyroidal $\mathrm{I}^{121}$.

Sodium salicylate, salicylamide, 2,5-, 2,6-, 3,5-dihydroxybenzoic acid, and $m$ - and $p$-hydroxybenzoic acid were obtained commercially. Salicyluric acid was synthesized by the method of Bondi (8), M.P. uncorrected equals $166^{\circ} \mathrm{C}$. Before injection the acids were neutralized to $\mathrm{pH} 6.0$; higher $\mathrm{pH}$ values were avoided to prevent air oxidation of the phenols. Total plasma "salicyl" (salicylate and salicylurate) and 2,6-dihydroxybenzoic acid were determined by a $\mathrm{Fe}^{+++}$ion method (9), at $530 \mathrm{~m} \mu$ and 560 $\mathrm{m} \mu$, respectively. Gentisic acid was determined after acidification of the serum or plasma to $\mathrm{pH} 5.5$ with 0.1 $\mathrm{M}$ acetate buffer either by a modified $\mathrm{Fe}^{+++}$ion method or with the phenol reagent $(10,11)$.

Goiter prevention experiments were carried out as

1 Supplied by the Armour Laboratories, Chicago, Ill. 
TABLE I

Response of thyroid uptake and serum protein bound iodine to exogenous thyrotropin during chronic salicylate administration

\begin{tabular}{|c|c|c|c|c|c|c|c|c|}
\hline \multirow[b]{3}{*}{ Patient } & \multicolumn{4}{|c|}{ Salicylate control } & \multicolumn{4}{|c|}{ Thyrotropin administration } \\
\hline & \multicolumn{3}{|c|}{ Radioiodine uptake (per cent) } & \multirow[b]{2}{*}{ PBI } & \multicolumn{3}{|c|}{ Radioiodine uptake (per cent) } & \multirow[b]{2}{*}{ PBI } \\
\hline & $2 \mathrm{hr}$. & $5 \mathrm{hr}$. & $24 \mathrm{hr}$. & & $2 \mathrm{hr}$. & $5 \mathrm{hr}$. & $24 \mathrm{hr}$ & \\
\hline $\begin{array}{l}\text { K. C. } \\
\text { R. P. } \\
\text { C. C. } \\
\text { R. B.* } \\
\text { J. L.* }\end{array}$ & $\begin{array}{l}3 \\
5 \\
8 \\
5 \\
3\end{array}$ & $\begin{array}{r}7 \\
10 \\
17 \\
8 \\
4\end{array}$ & $\begin{array}{r}19 \\
26 \\
26 \\
15 \\
6\end{array}$ & $\begin{array}{c}\mu g . \% \\
4.1 \\
3.7 \\
3.3 \\
5.0 \\
3.6\end{array}$ & $\begin{array}{r}33 \\
24 \\
12 \\
11 \\
9\end{array}$ & $\begin{array}{l}43 \\
40 \\
36 \\
20 \\
17\end{array}$ & $\begin{array}{l}66 \\
66 \\
64 \\
46 \\
27\end{array}$ & $\begin{array}{c}\mu g . \% \\
7.3 \\
7.1 \\
8.6 \\
8.6 \\
6.3\end{array}$ \\
\hline Mean & 5 & 9 & 18 & 3.9 & 18 & 31 & 54 & 7.6 \\
\hline
\end{tabular}
patients.

* Thyrotropin stimulation (10 U per day) for one day only, whereas given on three successive days to the other

previously described (5). High dietary levels of sodium salicylate were required to yield measureable effects but these could not be given from the start of the experiment because they led to considerable weight loss. On the other hand, when the sodium salicylate in the diet (Purina Lab Chow) was gradually increased 0.3 per cent per week until a level of 1.2 per cent was reached, no weight loss occurred. The rats were then divided into two groups, one receiving 0.1 per cent propylthiouracil together with the 1.2 per cent sodium salicylate in the diet, the other group, 1.2 per cent sodium salicylate only. Two other groups of rats served as controls-one untreated, the other receiving 0.1 per cent propylthiouracil in the diet. After 11 days on this regimen the thyroids were weighed and prepared for routine histological examination, and the thyroid to plasma (T/S) iodide ratio was determined as described previously (4).

Radioactive salicylic acid carboxyl $\mathrm{C}^{14}$ of specific activity, $1 \mu \mathrm{c}$. per $\mu \mathrm{M}$, was used to investigate localization of the drug. The radioactivity was 97 per cent salicylate as judged by ascending paper chromatography in $n$-butanol equilibrated with an equal volume of $2 \mathrm{~N} \mathrm{NH}_{4} \mathrm{OH}$ ( $\operatorname{Rf}$ equals 0.51 to 0.56 ), in $n$-butanol-dioxane $(80: 20)$ equilibrated with an equal volume of $2 \mathrm{~N} \mathrm{NH}_{4} \mathrm{OH}$ ( $\mathrm{Rf}$ equals 0.60 to 0.64$)$, in benzene-acetic acid- $\mathrm{H}_{2} \mathrm{O}(2: 2: 1)$, or in $n$-butanol-acetic acid- $\mathrm{H}_{2} \mathrm{O}(4: 1: 1)$ (12). The remaining radioactivity consisted of two separate bands, both of low $\mathrm{Rf}$ value. Chromatograms were scanned with a recording rate meter and also exposed to no-screen $\mathrm{X}$-ray film. The specific activity was sufficiently high so that small samples of tissue could be counted directly, without extraction or ashing. Two and five-tenths to 7.0 mg. of salicylate were injected intraperitoneally into male rats (100 to $150 \mathrm{Gm}$.) which were sacrificed and exsanguinated at intervals thereafter. Tissues were removed, ground with water in an all glass homogenizer, and an equivalent of 2 to $10 \mathrm{mg}$. of tissue (wet weight) was mounted on copper planchets and counted. Appropriate self absorption corrections were made.

\section{RESULTS AND DISCUSSION}

The responsiveness of the salicylate depressed thyroid gland to exogenous thyrotropin is illustrated in Table I. Both the PBI level and $I^{131}$ uptake showed striking elevations following TSH stimulation in five patients maintained on chronic salicylate therapy.

The administration of sodium salicylate markedly slowed the rate of release of thyroidal $\mathrm{I}^{131}$ (Figures 1 and 2), increasing the half-life from 10.7 and 12.4 days, respectively, to one too great for accurate definition. The reduction in release rate was apparent within 36 hours after beginning salicylate; on discontinuation of the drug the slope once again approximated that obtained prior to salicylate treatment (Figure 1). Since it has been demonstrated that one of the main actions of thyrotropin is to stimulate release of hormone from the gland (7), these results suggest that salicylates may in some manner interfere with the action of thyrotropin. That this interference is not due to an inability of the salicylate-depressed gland to respond to thyrotropin has already been noted in Table I. Inhibition of release of thyroidal $\mathrm{I}^{131}$ by salicylates (Figure 2) (serum concentration, 35 to $51 \mathrm{mg}$. per $100 \mathrm{ml}$.) is also readily overcome by exogenous thyrotropic stimulation despite continuation of salicylate administration. Furthermore, the acceleration of release of thyroidal $\mathrm{I}^{131}$, so characteristic of thyrotropic action (7), is not interrupted by salicylate administration sufficient to produce a blood level of 28 to $42 \mathrm{mg}$. per 100 
$\mathrm{ml}$. (Figure 3). Since the amount of TSH was greater than the minimal effective dose, it is still possible that a small decrease in sensitivity to TSH resulted from salicylate treatment but could not be demonstrated with the present method.

If the thyrotropin available to the thyroid is diminished by salicylates, this drug might be expected to interfere with goiter formation in propylthiouracil-treated rats. That this did occur is shown in Table II. Whereas propylthiouraciltreated rats showed thyroid gland enlargement to a mean weight of $26 \mathrm{mg}$. per $100 \mathrm{Gm}$. of body weight, the concomitant administration of sodium salicylate held the final mean thyroid weight to 13 mg. per $100 \mathrm{Gm}$. of body weight $(p \ll 0.001)$. Goiter prevention was not complete, however, since untreated and salicylate-treated controls had mean thyroid weights of approximately $7 \mathrm{mg}$. per 100 $\mathrm{Gm}$. body weight $(\mathrm{p}<0.001)$. Histological examination of the glands of some of the rats receiving both drugs simultaneously showed increased cell height and a moderate depletion of the colloid in the central follicles. Other glands closely

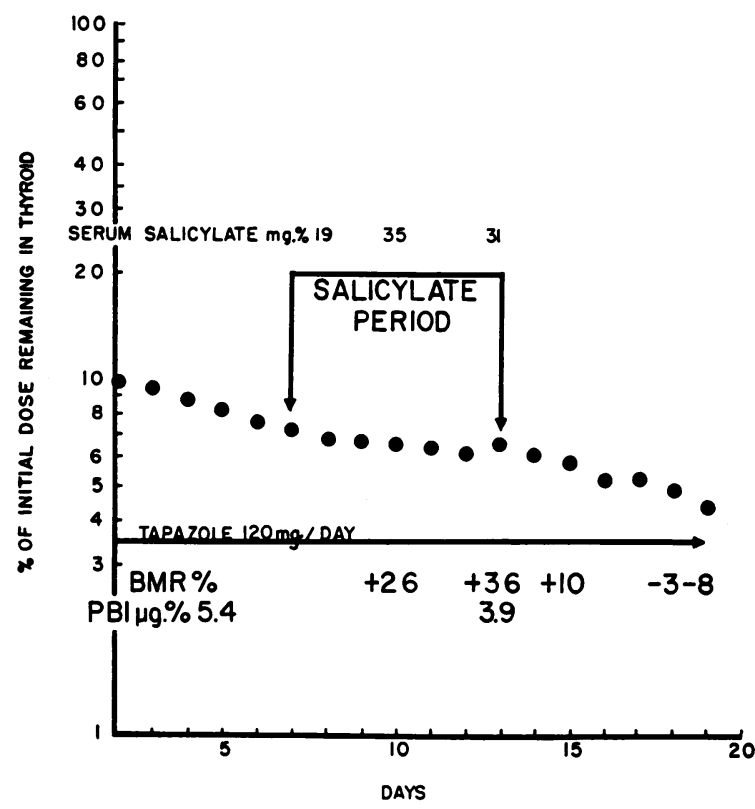

Fig. 1. The Effect of Salicylate Administration on the Release of Isi from the Human Thyroid GLAND

1-methyl-2-mercaptoimidazole was started 48 hours after an oral dose of $125 \mu \mathrm{c}$. of $\mathrm{I}^{131}$. Seven and twotenths $\mathrm{Gm}$. of sodium salicylate per day was given during the salicylate period. resembled the controls. This variability in the histological picture is reflected in the relatively large standard deviation of the thyroid weights of this group. In contrast, thyroids of propylthiouracil-treated rats showed the usual picture of complete absence of colloid and very tall collumnar epithelium with marked papillary infolding. Rats treated with salicylate and propylthiouracil tended to eat more of the diet than rats kept on propylthiouracil alone. Thus, the intake of goitrogen in the doubly treated group was at least that of the propylthiouracil controls. It is, however, still possible that the rate of metabolism of propylthiouracil was sufficiently increased by salicylate to lead to diminished goitrogenicity. Salicylate treatment alone led to minimal flattening of the epithelium and some pyknosis of the nuclei. The $\mathrm{T} / \mathrm{S}$ ratio of the salicylate and propylthiouracil-treated rats showed little change from the propylthiouracil group $(0.1<p<0.2)$. Results of the studies on the $\mathrm{T} / \mathrm{S}$ ratio and the histology closely resemble those of the incomplete goiter prevention observed with 2,4-dinitrophenol (5). It is probable that the discrepancy between thyroid weight and the $\mathrm{T} / \mathrm{S}$ ratio is further evidence that suppression of the $\mathrm{TSH}$ level is only partial, since the $\mathrm{T} / \mathrm{S}$ ratio is known to be more sensitive to slight thyrotropic stimulation (13).

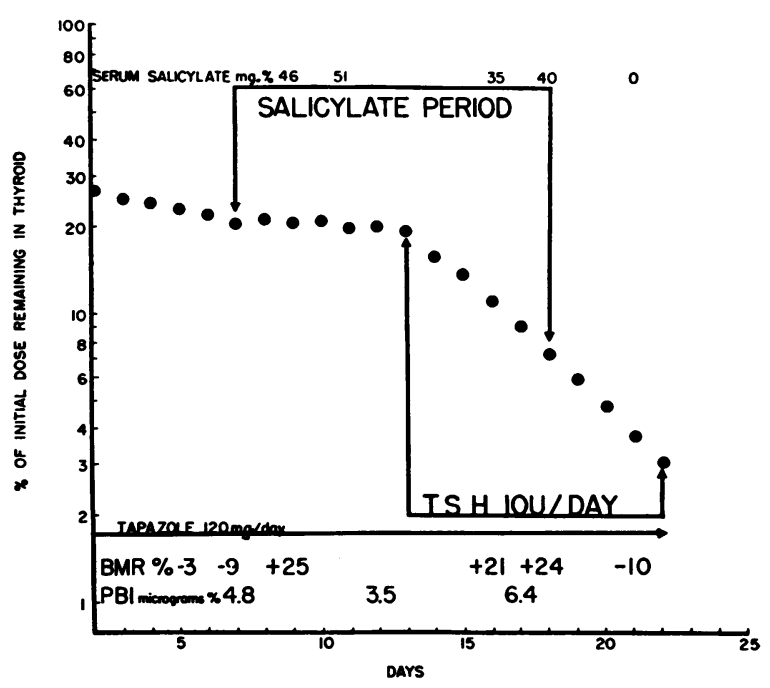

Fig. 2. The Effect of Salicylate Administration on the Release of $I^{131}$ from the Human Thyroid GLAND

Conditions as for Figure 1. Five U.S.P. units of thyrotropin was injected intramuscularly every twelve hours. 
TABLE II

Goiter prevention in rats by salicylate

\begin{tabular}{|c|c|c|c|c|}
\hline Treatment & $\begin{array}{l}\text { Mean } \\
\text { initial } \\
\text { weight }\end{array}$ & $\begin{array}{l}\text { Mean } \\
\text { final } \\
\text { weight }\end{array}$ & $\begin{array}{c}\text { Mean } \\
\text { thyroid } \\
\text { weight }\end{array}$ & $\begin{array}{l}\text { Mean } \\
\mathrm{T} / \mathrm{S} \text { ratio }\end{array}$ \\
\hline $\begin{array}{l}\text { Control }(10)^{*} \\
0.1 \% \text { propylthio- } \\
\text { uracil }(10)\end{array}$ & $\begin{array}{l}G m \\
121 \dagger \\
118 \dagger\end{array}$ & $\begin{array}{l}G m . \\
170 \\
142\end{array}$ & $\begin{aligned} & m g . / 100 \mathrm{Gm} . \\
& 6.6 \pm 0.66 \ddagger \\
& 26.2 \pm 6.7\end{aligned}$ & $\begin{array}{r}37 \pm 13 \ddagger \\
190 \pm 47\end{array}$ \\
\hline $\begin{array}{l}0.1 \% \text { propylthio- } \\
\text { uracil }+1.2 \% \text { sal- } \\
\text { icylate }(10)\end{array}$ & 141 & 140 & $12.7 \pm 3.9$ & $142 \pm 70$ \\
\hline $1.2 \%$ salicylate $(8)$ & 146 & 156 & $6.8 \pm 0.82$ & $32 \pm 14$ \\
\hline
\end{tabular}

* Numbers in parentheses indicate number of rats.

$\dagger$ Because of pretreatment of the salicylate groups, these animals were chosen so that the final weights would be approximately equal.

$\ddagger$ Standard deviation of the mean.

Diminished thyrotropic response seemed thus to be implicated, probably at a pituitary or higher level, and we were therefore interested in the report by Pallot and Eberhardt (14) that the $\mathrm{C}^{14}$ of carboxyl-labeled salicylate seemed to be concentrated in the adenohypophysis (tissue/serum ratio equals 0.7 for anterior pituitary, and 0.09 for the other organs). We were able to confirm a "relative" concentration of radioactivity in the anterior pituitary gland when compared to brain, but other organs showed a similar degree of concentration (Table III). Chromatographic analysis revealed that more than 90 to 95 per cent of the radioactivity of the tissues listed in Table III behaved like salicylate one hour after injection of labeled salicylate. In most tissues, including the anterior pituitary gland but not the brain or thyroid gland, traces of salicylglucuronide and salicyl-

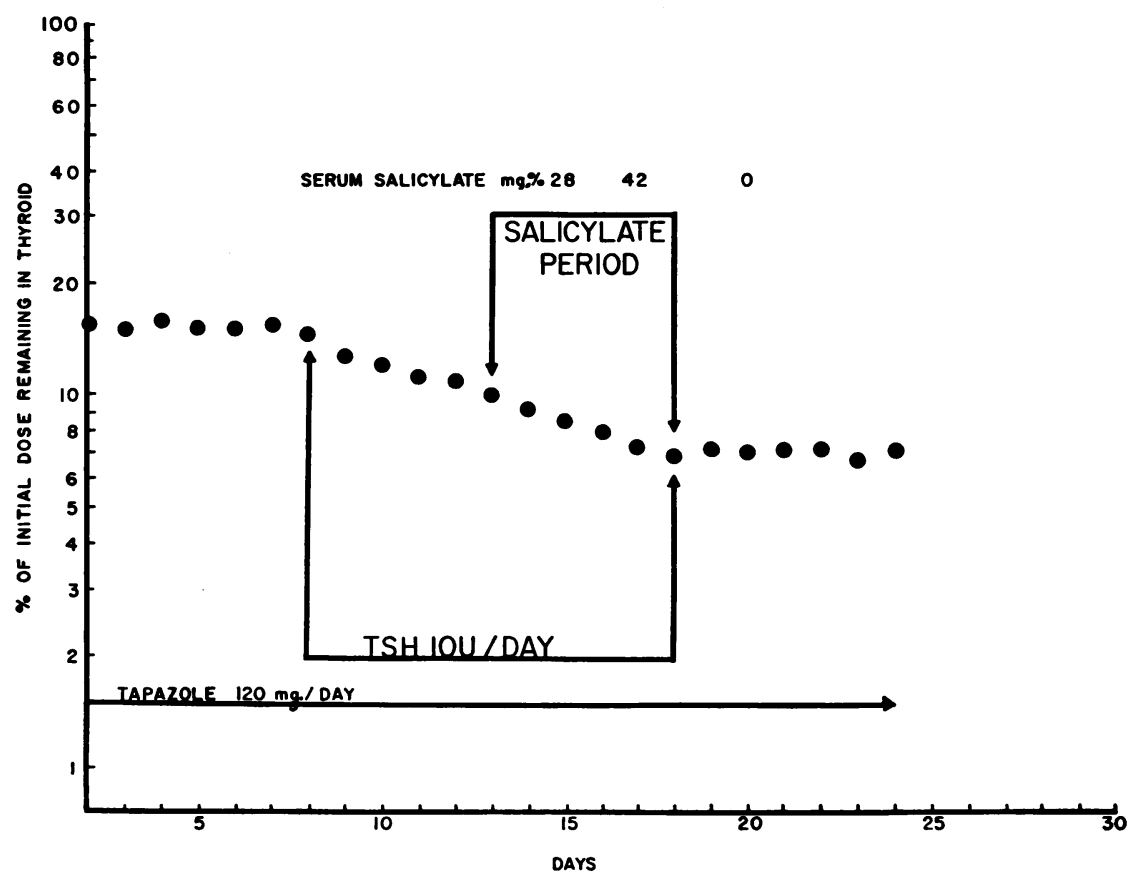

Fig. 3. The Effect of Salicylate Administration on the Release of I $^{131}$ from the Human Thyroid Gland

Conditions as in Figure 2. 
TABLE III

Distribution of salicylate $C^{14 *}$ in rat tissues

\begin{tabular}{|c|c|c|c|c|}
\hline \multirow[b]{2}{*}{$\begin{array}{l}\text { Interval after injection (hrs.). } \\
\text { No. of rats................. }\end{array}$} & \multicolumn{4}{|c|}{ Ratio of tissue $\mathrm{C}^{14}$ to plasma $\mathrm{C}^{14}$} \\
\hline & $\begin{array}{ll}.0 .5 \\
\ldots .2\end{array}$ & 1.0 & 2.0 & $\begin{array}{c}4.0 \\
2\end{array}$ \\
\hline Liver & 0.26 & 0.39 & 0.28 & 0.30 \\
\hline Kidney cortex & 0.53 & 0.53 & 0.67 & 0.54 \\
\hline Adrenal (whole gland) & 0.18 & 0.31 & 0.24 & 0.25 \\
\hline Spleen & 0.15 & 0.23 & 0.15 & 0.15 \\
\hline Testis & 0.14 & 0.18 & 0.13 & 0.16 \\
\hline Muscle (gastrocnemius) & 0.11 & 0.19 & 0.12 & 0.10 \\
\hline Heart (left ventricle) & 0.28 & 0.36 & 0.26 & 0.37 \\
\hline Lung & & 0.37 & 0.31 & 0.25 \\
\hline Thyroid gland & 0.23 & 0.43 & 0.25 & 0.27 \\
\hline Submaxillary gland & 0.21 & 0.28 & 0.21 & 0.22 \\
\hline Cerebral cortex & 0.06 & 0.12 & 0.06 & 0.07 \\
\hline "Hypothalamus" $\dagger$ & 0.11 & 0.10 & 0.10 & 0.07 \\
\hline Anterior pituitary & 0.13 & 0.29 & 0.30 & 0.24 \\
\hline Posterior pituitary & 0.07 & 0.07 & 0.09 & 0.16 \\
\hline Brain stem & 0.04 & 0.12 & 0.06 & 0.07 \\
\hline Cerebellum & 0.04 & 0.11 & 0.07 & 0.07 \\
\hline
\end{tabular}

* Specific activity of $1 \mu \mathrm{c}$. per $\mu \mathrm{M} ; 7$ to $24 \mu \mathrm{c}$. injected per rat intraperitoneally.

$\dagger$ Includes tuber cinereum and floor of third ventricle.

urate could be demonstrated on films exposed to chromatograms for two to four months. Too little activity was present to be detected by the scanner. In the liver, kidney and plasma, two to six per cent of the radioactivity behaved chromatographically as glucuronides, and in liver and kidney one to two per cent as gentisic acid. The latter could not be checked in alkaline solvents because of oxidation. Since the salicylate concentration is below that of the plasma, it appears likely that the effect is not specific and is possibly related to vascularity. It must be remembered, furthermore, that a drug need not be concentrated in the organ in which it acts, and conversely, that concentration in an organ does not prove it acts there specifically.

A comparison of the effect of release of $\mathrm{I}^{131}$ from the rat thyroid by salicylate with some of its congeners was undertaken in an attempt to study the mechanism of the inhibitory action. It has been reported that gentisic acid (2,5-dihydroxybenzoic acid $)(15,16)$ and $\gamma$-resorcylic acid $(2,6$ dihydroxybenzoic acid) (17) have antirheumatic activity, the latter in smaller dosage than either salicylate or gentisate. As shown in Table IV both of these drugs depress the release rate of thyroidal $\mathrm{I}^{131}$. On a dosage basis, $\gamma$-resorcylate was less active than salicylate; however, strict comparison is not possible, since blood levels com- parable to those obtained with sodium salicylate (about $50 \mathrm{mg}$. per $100 \mathrm{ml}$.) could never be attained with the diphenolic carboxylic acids, even when these were given every four hours and at three times the daily dose. Maximum blood levels attained were 2 to $11 \mathrm{mg}$. per $100 \mathrm{ml}$. for gentisate and 4 to $18 \mathrm{mg}$. per $100 \mathrm{ml}$. for $\gamma$-resorcylate (measured at 4 hours, i.e., just prior to the next injection). Similar difficulties in maintaining blood levels with gentisic acid have been encountered clinically $(15,16)$ but lower levels apparently suffice to obtain adequate therapeutic response.

\section{COMMENTS}

Thyroxine, dinitrophenol (DNP), and salicylate evoke many similar responses in man or the experimental animal (Table V). In addition to the similarities noted above, both salicylate and thyroxine accelerate intestinal absorption of glucose $(18,19)$, and all three agents can deplete the liver of glycogen (20-22) and uncouple oxidative phosphorylation $(23,24)$. However, the differences of these two phenols from thyroxine are well known, covering a range of effects from an inability to act as substitution therapy in myxedema $(25,26)$, to a failure to induce metamorphosis in the tadpole (27), to an inability to inhibit isolated dehydrogenases in vitro (28).

Nevertheless, the similarity in the alterations of the indices of thyroid function by these three agents (Table V) has led us to postulate that these changes are the consequence of some common action involving a reduction of the available TSH. What this action is remains to be discovered. The following possibilities have been considered.

It is tempting to correlate thyroid depression with the known ability of salicylate to uncouple oxidative phosphorylation, especially since dinitrophenol and thyroxine (23) are also uncoupling agents. On the basis of the dinitrophenol studies in the rat $(4,5)$, it had been postulated that the uncoupling action or the metabolic stimulation were possibly the factors common to agents that depress thyroid function via the pituitary gland. The present data make such a supposition less likely since a number of the dihydroxybenzoic acids that were found to depress $\mathrm{I}^{131}$ release from the rat thyroid (Table IV) neither raise the oxygen consumption in intact rats (32) nor uncouple 
TABLE IV

The effect of salicylate and some of its congeners of the release of $I^{181}$ from the rat thyroid

\begin{tabular}{|c|c|c|c|c|c|c|}
\hline Compound & $\begin{array}{l}\text { No. } \\
\text { of } \\
\text { rats }\end{array}$ & Dosage schedule & $\begin{array}{c}\text { Biological } \\
\text { half-life } \\
\text { before drug }\end{array}$ & $\begin{array}{l}\text { Biological } \\
\text { half-life } \\
\text { on drug }\end{array}$ & $\begin{array}{c}\text { Ratio of } \\
\text { half-life } \\
\text { on/off drug }\end{array}$ & Comment \\
\hline & & $\begin{array}{c}\text { mg./Kg. } \\
\text { subcutaneously }\end{array}$ & hours* & hours & & \\
\hline Salicylate & 5 & $\begin{array}{l}230 \text { twice daily } \\
+0.9 \% \text { in diet }\end{array}$ & 30 & 49 & 1.63 & $5 \%$ weight loss \\
\hline $\begin{array}{l}\text { (o-hydroxy- } \\
\text { benzoate) }\end{array}$ & $\begin{array}{l}4 \\
4\end{array}$ & $\begin{array}{l}280 \text { thrice daily } \\
130 \text { every } 4 \text { hrs. }\end{array}$ & $\begin{array}{l}36 \\
24\end{array}$ & $\begin{array}{r}124 \\
68\end{array}$ & $\begin{array}{l}3.44 \\
2.83\end{array}$ & $\begin{array}{l}9 \% \text { weight loss } \\
6 \% \text { weight loss }\end{array}$ \\
\hline Salicylurate & 4 & 490 twice daily & 50 & 46 & 0.92 & $9 \%$ weight loss \\
\hline Salicylamide & 6 & 280 thrice daily & 21 & 31 & 1.48 & $\begin{array}{l}\text { Marked transient } \\
\text { narcosis }\end{array}$ \\
\hline $\begin{array}{c}m \text {-hydroxy- } \\
\text { benzoate }\end{array}$ & 4 & 190 every 4 hrs. & 36 & $36+$ & 1.00 & Weight unchanged \\
\hline $\begin{array}{l}p \text {-hydroxy- } \\
\text { benzoate }\end{array}$ & 5 & 190 every 4 hrs. & 25 & $25 \ddagger$ & 1.00 & Weight unchanged \\
\hline \multirow{2}{*}{$\begin{array}{l}\text { Gentisate } \\
(2,5 \text {-dihy- } \\
\text { droxy-ben- } \\
\text { zoate) }\end{array}$} & 5 & 150 every 4 hrs. & 28 & 40 & 1.43 & Weight unchanged \\
\hline & 5 & 320 every 4 hrs. & 17 & 35 & 2.06 & $5 \%$ weight loss \\
\hline \multirow{2}{*}{$\begin{array}{l}\gamma \text {-resorcyl- } \\
\text { ate }(2,6-\text { di- } \\
\text { hydroxyben- } \\
\text { zoate) }\end{array}$} & 5 & 160 every 4 hrs. & 29 & 35 & 1.21 & Weight unchanged \\
\hline & 5 & 320 every 4 hrs. & 21 & 50 & 2.38 & $5 \%$ weight loss \\
\hline \multirow{2}{*}{$\begin{array}{l}\alpha \text {-resorcyl- } \\
\text { ate }(3,5-\text { di- } \\
\text { hydroxyben- } \\
\text { zoate) }\end{array}$} & 5 & 160 every 4 hrs. & 23 & 31 & 1.35 & Weight unchanged \\
\hline & $\begin{array}{l}5 \\
5\end{array}$ & $\begin{array}{l}320 \text { every } 4 \mathrm{hrs} \text {. } \\
380 \text { every } 4 \mathrm{hrs} \text {. }\end{array}$ & $\begin{array}{l}23 \\
27\end{array}$ & $\begin{array}{l}36 \\
46\end{array}$ & $\begin{array}{l}1.56 \\
1.70\end{array}$ & $\begin{array}{l}\text { Weight unchanged } \\
\text { Weight unchanged }\end{array}$ \\
\hline $\begin{array}{l}\text { 2,4-dinit- } \\
\text { rophenol }\end{array}$ & 7 & $0.2 \%$ in diet & 25 & 82 & 3.28 & (4) \\
\hline DL-thyroxine & 5 & 0.075 daily & 34 & 26 days & $\sim 18$ & (7) \\
\hline
\end{tabular}

* Variation of the release rate of control rats is in part caused by different feeding periods on the low iodine diets. Since each animal is its own control this error is eliminated.

† Low iodine diet supplemented with Purina Lab Chow. All other rats pretreated with low iodine diet alone.

$\ddagger$ A change in half-life of under 10 per cent would not be detected by this technique.

oxidative phosphorylation at concentrations in excess of those found in the circulation (24). ${ }^{2}$

The observation that pyrogens or an elevated ambient temperature can depress thyroid function

2 Dr. Packer has kindly tested the 2,4-, 2,5-, 2,6-, dihydroxybenzoates and the meta- and parahydroxybenzoic acids in rat heart mitrochondria utilizing $\alpha$-ketoglutarate, and has found that none of these phenols uncouple oxidative phosphorylation at concentrations as high as $2.5 \times$ $10^{-3} \mathrm{M}$ (33). It should also be pointed out that the uncoupling of thyroxine differs from the two other phenols. All three agents uncouple oxidative phosphorylation in intact mitochondria, but thyroxine fails to uncouple in mitochondria fragmented with digitonin, where dinitrophenol and salicylate are still active (34). Furthermore, uncoupling induced by thyroxine is sensitive to the concentration of $\mathrm{Mg}^{++}$, whereas that of other phenols is not $(35,36)$. in rats as the body temperature is elevated (5) suggested that fever might be a factor in producing thyroid inhibition. However, the production of fever is not required since none of the patients described in the previous paper (1) had temperature elevation. Weight loss, though it can result from treatment with any of these agents and may be associated with a depression in the butanol-extractable iodine of serum (37), appears not to be essential since rats not exhibiting weight loss show similar thyroid depression $[(5)$ and Table IV], and the salicylate-treated patients described in the previous paper (1) did not lose weight unless dietary intake was fixed. Moreover, patients on thyroid hormone therapy may 
TABLE $\mathbf{V}$

Comparison of peripheral and thyroidal effects of thyroxine, salicylate and 2,4-dinitrophenol

\begin{tabular}{lcccl}
\hline \hline & $\begin{array}{c}\text { Thyroid } \\
\text { hormone }\end{array}$ & Salicylate & $\begin{array}{c}\text { 2,4-dinitro- } \\
\text { phenol }\end{array}$ & References \\
\hline $\begin{array}{l}\text { Metabolic rate } \\
\text { Urine creatine }\end{array}$ & $\uparrow^{*}$ & $\uparrow$ & $\uparrow$ & $(1,29,30)$ \\
$\begin{array}{l}\text { Serum cholesterol in hypothy- } \\
\text { roidism }\end{array}$ & $\uparrow$ & $\uparrow$ & $\uparrow$ & $(1,26)$ \\
$\begin{array}{l}\text { Glucose absorption } \\
\text { Liver glycogen }\end{array}$ & $\uparrow$ & $\downarrow$ & & $(18,19)$ \\
$\begin{array}{l}\text { Oxidative phosphorylation } \\
\text { Thyroid I'13 uptake }\end{array}$ & $\downarrow$ & $\downarrow$ & & $(20-22)$ \\
Thyroid I'131 clearance & $\downarrow$ & $\downarrow$ & $\downarrow \uparrow$ & $(23,24)$ \\
$\begin{array}{l}\text { Release of thyroidal I'131 } \\
\text { Serum protein-bound iodine }\end{array}$ & $\downarrow$ & $\downarrow$ & $\downarrow$ & $(1,4)$ \\
Fractional rate of thyroxine & $\downarrow$ & $\downarrow$ & $\downarrow$ & $(4,7)$ \\
disappearance from circulation & $\downarrow$ & $\downarrow$ & $\downarrow$ & $(1-4)$ \\
$\begin{array}{l}\text { Goiter prevention } \\
\text { Myxedema therapy }\end{array}$ & $\uparrow \S$ & $\uparrow$ & $\uparrow$ & $(1,4,31)$ \\
Tadpole metamorphosis & $\uparrow$ & $\uparrow \|$ & $\uparrow \|$ & $(5)$ \\
Dehydrogenase activity & $\uparrow$ & 0 & 0 & $(25,26)$ \\
\hline
\end{tabular}

$* \uparrow$ refers to an increase or stimulation (or replacement in myxedema); $\downarrow$ refers to a decrease or inhibition; 0 means no effect.

† Initial depletion followed by an increase.

$\ddagger$ After triiodothyronine treatment.

$\$$ In thyrotoxicosis.

\| Only partial.

exhibit thyroid inhibition in the absence of weight loss.

A theory of action that has been proposed for salicylates is that which emphasizes ortho-phenolic substitution and the chelation resulting from internal hydrogen bonding (17). Two possible effects might be involved: $a$ ) replacement of the hydrogen by some metal ion required for enzymatic reactions, and $b$ ) stabilization of the carboxylate anion leading to increased acidity, especially in the case of the di- ortho-substituted $\gamma$-resorcylate (38). The fact that gentisate and $\gamma$-resorcylate possess activity would be consistent with this formulation as would the inactivity of the $m$ - and p-hydroxybenzoic acids (Table IV). However, 3,5-dihydroxybenzoic acid inhibits the release of $\mathrm{I}^{131}$ from the gland. Unless one would invoke conversion to an ortho-substituted product, it would seem unlikely that the chelation concept can be made to fit the data. The conversion to an active quinonoid intermediate (39) is also unlikely in this compound.

Since adrenal stimulation has been repeatedly suggested as a mechanism for salicylate action
(40), it is important to consider this as a possible means of depressing thyroid function. Although the literature on the relation of the adrenals to the thyroid is extremely confusing (41), large doses of cortisone appear to be required in the rat to suppress iodine uptake, and only enormous doses ( $50 \mathrm{mg}$. per $\mathrm{Kg}$. per day) depress release of $\mathrm{I}^{131}$ from the gland (42-45). Three mg. of cortisone per day did not prevent goiter formation (42). Furthermore, certain of the effects on the thyroid appear to be related to an augmented renal clearance of iodide (41) which did not occur in patients on salicylate therapy (1). That the adrenal is not required for dinitrophenol action was shown by the fact that goiter prevention by dinitrophenol still occurred in adrenalectomized rats maintained on constant parenteral hydrocortisone (5). In man treated with DNP, no change could be demonstrated in the eosinophile count or the urinary 17-ketosteroids (3). Finally, Peterson, Black, and Bunim (40) have shown that salicylate administration in man did not increase the plasma concentration or the rate of metabolism of hydrocortisone or corticosterone, or the urinary excre- 
tion of corticosteroids and 17-ketosteroids. An adrenal mechanism thus appears to be unlikely. Sensitization to the sympathomimetic amines is also not essential, since this is not a characteristic of salicylate-induced hypermetabolism (46).

Lastly, the evidence that both thyroxine and dinitrophenol (47) increase the disappearance rate of exogenous thyrotropin from the circulation does not afford a satisfactory explanation. If this were the reason for the inhibition of thyroid function, histologic evidence of pituitary activation might be expected. This, however, is not the case -both thyroxine and dinitrophenol treatment lead to normal or "inactive" pituitary cytology (5). Although a temporary rise in pituitary basophils had been reported following salicylate administration to rats (14), the cell type has not been identified as that characteristic of "thyrotrophs." Furthermore, the rise was not sustained, whereas the thyroid inhibition in man is demonstrable months after the onset of salicylate therapy.

It appears, therefore, that the TSH-inhibiting properties of the thyroid hormones can be mimicked by a number of agents that do not possess thyromimetic activity in many other respects, and that the mechanism of the inhibitory effect remains, at present, obscure.

\section{SUM MARY}

1. The effect of salicylate on some thyrotropindependent functions of the thyroid gland has been investigated in man and rats.

2. The thyroid of salicylate-treated patients responds to exogenous thyrotropin with an increase in uptake of $\mathrm{I}^{131}$, an elevation of the serum protein bound iodine concentration, and an accelerated rate of release of $\mathrm{I}^{\mathbf{1 3 1}}$ from the gland.

3. Salicylate treatment leads to partial inhibition of goitrogenesis in propylthiouracil-treated rats.

4. Salicylate- $\mathrm{C}^{14}$ does not appear to be significantly concentrated in the pituitary gland, hypothalamus, thyroid or adrenal.

5. Salicylate and a variety of its congeners retard the release of $\mathrm{I}^{131}$ from the rat thyroid gland.

6. It is concluded from these findings that the inhibition of thyroid gland function produced by salicylate therapy is mediated via an inhibition of thyrotropic stimulation at a pituitary or higher level. The mechanism of this effect has not been elucidated. It appears not to be related to the uncoupling of oxidative phosphorylation, pyrogenesis, chelating ability of ortho-substituted phenols, or adrenal stimulation.

7. A comparison of some actions of thyroxine, 2,4-dinitrophenol, and salicylate is presented.

\section{ACKNOWLEDGMENTS}

The authors gratefully acknowledge the advice of Dr. J. E. Rall and the technical assistance of Mr. John J. Goldsberry.

\section{REFERENCES}

1. Austen, F. K., Rubini, M. E., Meroney, W. H., and Wolff, J. Salicylates and thyroid function. I. Depression of thyroid function. J. clin. Invest. 1958, 37, 1131.

2. Wolff, J., Rubin, L., and Chaikoff, I. L. The influence of 2,4-dinitrophenol on plasma protein-bound iodine. J. Pharmacol. exp. Ther. 1950, 98, 45.

3. Castor, C. W., and Beierwaltes, W. The effect of 2,4-dinitrophenol on thyroid function in man. $\mathrm{J}$. clin. Endocr. 1956, 16, 1026.

4. Goldberg, R. C., Wolff, J., and Greep, R. O. The mechanism of depression of plasma protein bound iodine by 2,4-dinitrophenol. Endocrinology 1955, 56, 560.

5. Goldberg, R. C., Wolff, J., and Greep, R. O. Studies on the nature of the thyroid-pituitary interrelationship. Endocrinology 1957, 60, 38.

6. Goldsmith, R. E., Stanbury, J. B., and Brownell, G. L. The effect of thyrotropin on the release of hormone from the human thyroid. J. clin. Endocr. 1951, 11, 1079.

7. Wolff, J. Some factors that influence the release of iodine from the thyroid gland. Endocrinology 1951, 48, 284.

8. Bondi, S. Synthese der Salicylursäure. Z. physiol. Chem. 1907, 52, 170.

9. Keller, W. J., Jr. A rapid method for the determination of salicylates in serum or plasma. Amer. J. clin. Path. 1947, 17, 415.

10. Gerald, P. S., and Kagan, B. M. A method for the determination of gentisic acid in serum. J. biol. Chem. 1951, 189, 467.

11. Roseman, S., and Dorfman, A. The determination and metabolism of gentisic acid. J. biol. Chem. 1951, 192, 105.

12. Haberland, G. L., Medenwald, M., and Köster, L. Stoffwechselendprodukte der Salicyl-, Acetylsalicyl-, Gentisin- und Salicylursäure im Rattenurin. Hoppe-Seylers Z. physiol. Chem. 1957, 306, 235.

13. Bogdanove, E. M., and Bogdanove, J. N. Thyroid weight, microscopic structure, and radioiodide concentration at various levels of thyrotropin secretion in the goitrogen-treated rat. Endocrinology 1957, 61, 52. 
14. Pallot, G., and Eberhardt, H. Distribution quantitative du salicylate marqué $\left(\mathrm{C}^{14}\right)$ dans l'organisme du rat. C. R. Soc. Biol. (Paris) 1956, 150, 1220.

15. Meyer, K., and Ragan, C. The antirheumatic effect of sodium gentisate. Science 1948, 108, 281.

16. Clarke, N. E., Mosher, R. E., and Clarke, C. N. Phenolic compounds in the treatment of rheumatic fever. Circulation 1953, 7, 247.

17. Reid, J., Watson, R. D., Cochran, J. B., and Sproull, D. $H$. Sodium $\gamma$-resorcylate in rheumatic fever. Brit. med. J. 1951, 2, 321.

18. Althausen, T. L., and Stockholm, M. Influence of the thyroid gland on absorption in the digestive tract. Amer. J. Physiol. 1938, 123, 577.

19. Smith, M. J. H. The effect of salicylate on glucose tolerance in the rat. Biochim. biophys. Acta 1954, 14, 241.

20. Barnes, J. M. The effect of dinitro-o-cresol on the deposition of liver glycogen in the rat. Biochem. J. 1953, 54, 148.

21. Smith, M. J. H. The effect of salicylate on liver glycogen in the rat. Biochem. J. 1954, 57, 349.

22. Fonnesu, A., and Severi, C. Glycogen accumulation in the liver due to 2:4-dinitrophenol. Brit. J. exp. Path. 1955, 36, 35.

23. Lardy, H. A., and Maley, G. F. Metabolic effects of thyroid hormones in vitro. Recent Progr. Hormone Res. 1954, 10, 129.

24. Brody, T. M. Action of sodium salicylate and related compounds on tissue metabolism in vitro. J. Pharmacol. exp. Ther. 1956, 117, 39.

25. Dodds, E. C., and Robertson, J. D. The clinical applications of dinitro-o-cresol. Lancet 1933, 225, 1137 and 1197.

26. Alexander, W., and Johnson, K. W. A comparison of the effects of acetylsalicylic acid and DL-triiodothyronine in patients with myxoedema. Clin. Sci. 1956, 15, 593.

27. Cutting, C. C., and Tainter, M. L. Comparative effects of dinitrophenol and thyroxine on tadpole metamorphosis. Proc. Soc. exp. Biol. (N. Y.) 1933, 31, 97.

28. Wolff, J., and Wolff, E. C. The effect of thyroxine on isolated dehydrogenases. Biochim. biophys. Acta 1957, 26, 387.

29. Pugsley, L. I. The effect of 2:4-dinitrophenol upon calcium, creatine and creatinine excretion in the rat. Biochem. J. 1935, 29, 2247.

30. Terroine, Th. Phénols nitrés et metabolisme azoté. Arch. int. Pharmacodyn. 1945, 71, 377.
31. Sterling, K., and Chodos, R. B. Radiothyroxine turnover studies in myxedema, thyrotoxicosis, and hypermetabolism without endocrine disease. J. clin. Invest. 1956, 35, 806.

32. Meade, B. W. Effect of certain hydroxybenzoic acids on the oxygen consumption of Wistar rats. Ann. rheum. Dis. 1954, 13, 60 .

33. Packer, L. Coupled phosphorylation in rat heart sarcosomes. Arch. Biochem. 1957, 70, 290.

34. Lehninger, A. L. Personal communication.

35. Bain, J. A. The effect of magnesium upon thyroxine inhibition of phosphorylation. J. Pharmacol. exp. Ther. 1954, 110, 2.

36. Mudd, S. H., Park, J. H., and Lipmann, F. Magnesium antagonism of the uncoupling of oxidative phosphorylation by iodo-thyronines. Proc. nat. Acad. Sci. (Wash.) 1955, 41, 571.

37. Durham, J. R., Cooke, R. E., Lancaster, J. W., and Man, E. B. Serum butanol-extractable iodine values of children under ten years of age. Amer. J. Dis. Child. 1954, 87, 468.

38. Baker, W. Abnormal strength of 2:6-dihydroxybenzoic acids. Nature (Lond.) 1936, 137, 236.

39. Roof, B. S., and Turner, J. C. Protein interactions of gentisic acid and certain of its oxidation products. J. clin. Invest. 1955, 34, 1647.

40. Peterson, R. E., Black, R. L., and Bunim, J. J. Salicylates and adrenocortical function in man. Arth. Rheum. 1958, 1, 29.

41. Ingbar, S. H., and Freinkel, N. The influence of $\mathrm{ACTH}$, cortisone, and hydrocortisone on the distribution and peripheral metabolism of thyroxine. J. clin. Invest. 1955, 34, 1375.

42. O'Neal, L. W., and Heinbecker, P. Failure of cortisone to influence thyroid function. Endocrinology 1953, 53, 239.

43. Perry, W. F. The action of cortisone and ACTH on thyroid function. Endocrinology 1951, 49, 284.

44. Albert, A., Tenney, A., and Ford, E. The effect of cortisone and corticotropin on the biologic decay of thyroidal radioiodine. Endocrinology 1952, 50, 324.

45. Brown-Grant, K. Inhibition of the release of thyroidal radioiodine in the rat by cortisone. Endocrinology 1955, 56, 607.

46. Joy, R. J. T., and Austen, F. K. The response to catechol amine infusion during salicylate-induced hypermetabolism in man. Circulat. Res. In press.

47. D'Angelo, S. A. The metabolism of thyrotrophic hormone in the rat. Endocrinology 1955, 56, 37. 